
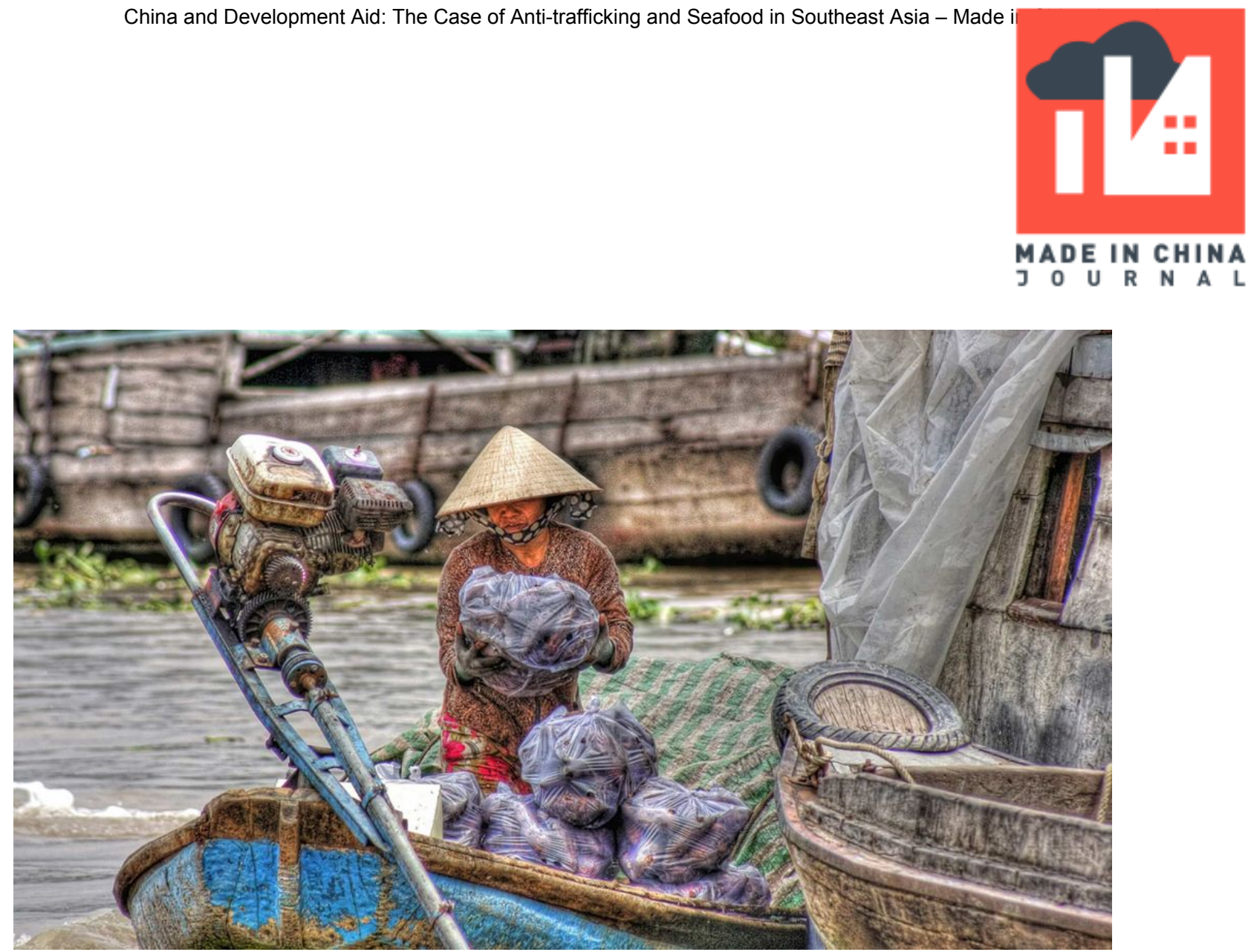

\title{
China and Development Aid: The Case of Anti-trafficking and Seafood in Southeast Asia
}

Written On 7 July 2018. Posted In Article, Window On Asia.

Author: Sverre Molland

WMade In China: Anybody Out There? April-July 2018

Back in the early 2000s, I had an informal conversation with a social impact advisor from the Asian Developed Bank (ADB) regarding the impact of Chinese aid in Laos. The advisor told me that she was concerned about the increasing influence of China on the Lao government, as it made ADB's development strategy ineffective. As Chinesefunded infrastructure did not require either mitigation strategies or environmental and social impact assessments, it made it harder for ADB (and others) to insist on such measures. Due do China's increasing prominence, she alleged, ADB risked cancelling 
itself out of the competitive market of infrastructure development contracts in Laos, thus losing any ability to safeguard basic social, environmental, and human rights standards.

In this essay, I use this anecdote as a point of departure to consider China's impact on another important issue within the Mekong countries: labour migration. The predicament of this ADB advisor highlights the difficulties of imposing developmentled social and environmental conditionalities within a context of increasing dominance of Chinese aid. Furthermore, although infrastructure projects constitute state-led development, they take place within a neoliberal aid environment where market mechanisms structure how development actors project human rights-based conditionalities. I suggest that current efforts to introduce humanitarian and human rights standards in labour migration-commonly through discourses of anti-trafficking and modern slavery-signal a shift away from state to market actors in development. Although it may seem to bypass state-centric responses to labour exploitation, this new strategy may face a similar dilemma to the ADB consultant mentioned above due to China's growing role in the region. This, as we will see below, can be seen in the seafood industry.

\section{Development-migration Nexus between China and the Mekong Region}

One of the central changes to development aid in the Mekong region has been the ascendance of China as a bilateral aid actor. This is particularly pertinent in countries, such as Laos, where Chinese-led infrastructure, commercial agriculture, mining, and extraterritorial casinos have received considerable scholarly attention (Baird 2011; Diana 2018; Nyíri 2012; Tan 2014). The construction of a Chinese railway connecting mainland China with its Southeast Asian neighbours is one of the latest steps within this larger trend. In a country like Laos, it is a well-known fact among aid practitioners that although western-based development assistance may have been dominant in the recent past, it is increasingly looking like a sideshow compared to Chinese aid and investment.

Parallel to this shift, given the strong focus of ASEAN and Mekong countries on infrastructure development-especially road construction-and the liberalisation of trade and mobility, labour migration has also become a central pillar in the region's development efforts. For this reason, the aid sector has given increasing attention to the development-migration nexus in the Mekong region. Partly dovetailing with the European Union, ASEAN recently introduced an internal skilled migration mobility 
programme under the auspices of the ASEAN Economic Community (AEC). Still, the number of skilled migrants who can now travel freely thanks to this initiative is dwarfed by the huge amount of unskilled migrants who form the backbone of key economic sectors, such as agriculture, construction, and seafood processing. Although numbers are imprecise, in Thailand alone the unskilled labour migration population is estimated to be several million (Auethavornpipat 2017).

To date, labour migration from China to Mekong countries has been limited and primarily concerned with the Chinese labour exodus in the context of Chinese-backed investment. In fact, the main connection between China and the Mekong countries in relation to migration has arguably been through more sinister sides of migration, in particular human trafficking. For example, the United Nations has pointed to the considerable outmigration of young women from Myanmar and Laos to China, where concerns are being raised about possible trafficking and forced marriages (UNIAP 2013). Anti-trafficking has also been a central conduit for China's multilateral cooperation with Mekong governments, such as the Memorandum of Understanding on Cooperation against Trafficking in Persons in the Greater Mekong Sub-region (COMMIT), which has served as the main vehicle for multilateral engagement on antitrafficking among Mekong countries since its conception in 2004.

Yet to fully grasp the importance of China in relation to migration and development in the Mekong region it is important to grasp how anti-trafficking discourses and practices have changed in recent years.

\section{From State to Market Anti-trafficking Discourses}

In the Mekong region, the earliest anti-trafficking interventions by development aid actors emerged during the 1990s, with the first interventions being framed as povertyreduction strategies. However, in the subsequent decades the sector followed a global trend to include a strong law enforcement focus, coupled with awareness-raising efforts and support for victims (Molland 2012). In other words, anti-trafficking became heavily state-centric as law enforcement and immigration authorities came to play central roles in anti-trafficking responses.

Yet, anti-trafficking has faced sustained criticisms both from academics and practitioners who point out that interventions often are counterproductive, tend to prioritise border control agendas, and-partly as a result of the latter-end up working against the very people they aim to assist (Anderson 2012; Keo et al. 2014). In Mekong countries, these criticisms are paralleled by a notable donor and programme fatigue 
within the anti-trafficking sector. Other nomenclatures, such as 'modern slavery', have gained momentum. In contrast to anti-trafficking interventions, modern slavery places stronger focus on consumers and the corporate sector's possible complicity in exploitative and 'slave-like' labour, and enjoys considerable financial backing from philanthro-capitalists such as Australia's mining millionaire Andrew Forrest and eBay's founder Pierre Omidyar. Rather than an explicit focus on border control and police, modern slavery broadens activities to focus on 'supply chain governance' and consumer ethics. Governments too, such as Australia, the United Kingdom, and California, have all promulgated legislation that mandates companies to report on their efforts to clean up their supply chains.

While the modern slavery discourse has also been forcefully critiqued (Gallagher 2017), it is notable how it broadens activism from the state to market. Although this discourse has only recently crept into Mekong-based NGOs and UN agencies, it is striking how in that context a previous concern with 'sex trafficking' has been largely replaced with concerns regarding slavery-like work conditions, with particular attention to the Thai seafood sector. It is also here that we see the discourse of supply chain governance opening up a space where it becomes possible to think about consumer boycotts. In Thailand this has become a political reality, with the European Union threating a boycott of Thai seafood on environmental (overfishing) and humanitarians grounds (abusive labour). In contrast to ongoing political pressure from the United States government through its annual Trafficking in Persons Report where Thailand has been routinely poorly ranked-a potential seafood boycott has a far larger impact: the former is primarily a question of losing political face; the latter will seriously affect the Thai economy. As such, it is precisely this kind of action that advocates of 'modern slavery' suggest can have a positive impact on the work conditions of poor, unskilled migrant workers in the Mekong region and beyond.

\section{China and Seafood}

At first glance, China appears entirely absent from these developments. Although the Chinese authorities engage with the region on human trafficking issues, they do not seem to have picked up on the emerging modern slavery agenda in dealing with their neighbours. Nor is China a central consumer of Thai seafood. Yet, this can all easily change, and for a very simple reason.

Today, China accounts for 35 percent of total global fish production and 30 percent of global consumption (World Bank and FAO 2013). Although China has a substantial domestic seafood production, it is already the third largest importer of seafood in the 
world. Its role as a seafood consumer is set to increase significantly in the next few years, as the country is the fastest growing consumer of seafood globally (World Bank and FAO 2013). Given the regional proximity of Southeast Asia, countries like Thailand may become a growing market to cater to China's seafood consumption.

To date, there is no notable human rights discourse or insistence on human rightsbased conditionalities relating to Chinese consumer markets and imports. Yet, there seems to be a surprising lack of reflection amongst United Nations agencies and NGO practitioners regarding how China can influence their strategies. Soon, anti-trafficking and modern slavery abolitionists may find themselves in a similar situation to the ADB consultant mentioned at the beginning of this essay: either pursue a strategy of imposing conditionalities, thus effectively locking yourself out of the very market you attempt to impact, or simply abandon any attempt to impose ethical conditions.

\section{Two Lessons}

There are two main lessons to be drawn from all this. First, tragicomically, the end result may be similar to what has been observed in the fair-trade movement more broadly: moulding markets into humane emancipatory projects which ensure fair prices is hard to achieve in practice. Yet, one thing such market-based initiatives do achieve is to commodify social movements. Hence, despite an official claim of aid actors to be transforming markets into ethical practices, the reverse is actually taking place: markets transform aid actors.

Second, if consumers of seafood are meant to be a central actor in the eradication of 'modern slavery' in Thailand's fishing sector through ethically based conditionalities within seafood trade, it is difficult to see how this will be effective within the context of China's emerging role as a seafood consumer. Philanthro-capitalist initiatives, such as the modern slavery agenda, may unintentionally open another space within the aid sector where China will be able to dominate just as it already does in other spheres. In the long run, a 'modern slavery' agenda in the Mekong region may end up marginalising its own space of humanitarian consumer activism, and China's growing importance in the region is at the heart of this process.

Photo Credits: Daniel Mennerich 
Anderson, Bridget. 2012. "Where's the Harm in That? Immigration Enforcement, Trafficking, and the Protection of Migrants' Rights." American Behavioral Scientist 56, no. 9: 1241-1257.

Auethavornpipat, Ruji. 2017. "Assessing Regional Cooperation: ASEAN States, Migrant Worker Rights and Norm Socialization in Southeast Asia." Global Change, Peace \&amp; Security 29, no. 2: 129-143.

Baird, Ian G. 2011. "Turning Land into Capital, Turning People into Labor: Primitive Accumulation and the Arrival of Large-scale Economic Land Concessions in the Lao People's Democratic Republic." New Proposals: Journal of Marxism and Interdisciplinary Inquiry 5, no. 1: 10-26.

Diana, Antonella. 2018. "Liquid Labourscape: Ad Hoc Experimentation in a Chinese Special Economic Zone in Laos." In Made in China Yearbook 2017: Gilded Age, edited by Ivan Franceschini and Nicholas Loubere, 80-83. Canberra: ANU Press.

Gallagher, Anne T. 2017. "What's Wrong with the Global Slavery Index." Anti-Trafficking Review no. 8.

Keo, Chenda, Thierry Bouhours, Roderic Broadhurst, and Brigitte Bouhours. 2014. "Human Trafficking and Moral Panic in Cambodia." The ANNALS of the American Academy of Political and Social Science 653, no. 1: 202-224.

Molland, Sverre. 2012. The Perfect Business? Anti-Trafficking and the Sex Trade Along the Mekong. Honolulu: University of Hawaii Press.

Nyíri, Pál. 2012. "Enclaves of Improvement: Sovereignty and Developmentalism in the Special Zones of the China-Lao Borderlands." Comparative Studies in Society and History 54, no. 3: 533562.

Tan, Danielle. 2014. "Chinese Networks, Economic and Territorial Redefinitions in Northern Lao PDR." In Transnational Dynamics in Southeast Asia, edited by Sirivanh Khntaphane, Christian Taillard, and Nathalie Fau, 422-452. Singapore: Institute of Southeast Asian Studies.

UNIAP. 2013. Report on an Exploratory Research about Migration and Human Trafficking to China in Luang Namtha and Phongsaly, Lao PDR. Vientiane: UNIAP. 
World Bank and FAO. 2013. Fish to 2030: Prospects for Fisheries and Aquaculture. Washington: World Bank Report Number 83177-Glb.

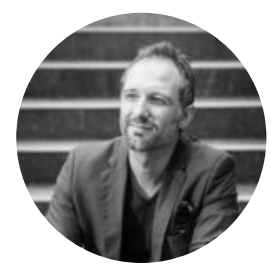

Sverre Molland

Sverre Molland is a Senior Lecturer in Anthropology at the Australian National University. His research examines the intersections between migration, development, and security in a comparative perspective, with specific focus on governance regimes and intervention modalities in mainland Southeast Asia. He has published extensively on human trafficking and labour migration in Southeast Asia and is the author of The Perfect Business? Anti-Trafficking and the Sex Trade along the Mekong (University of Hawaii Press 2012).

\section{Latest Articles}

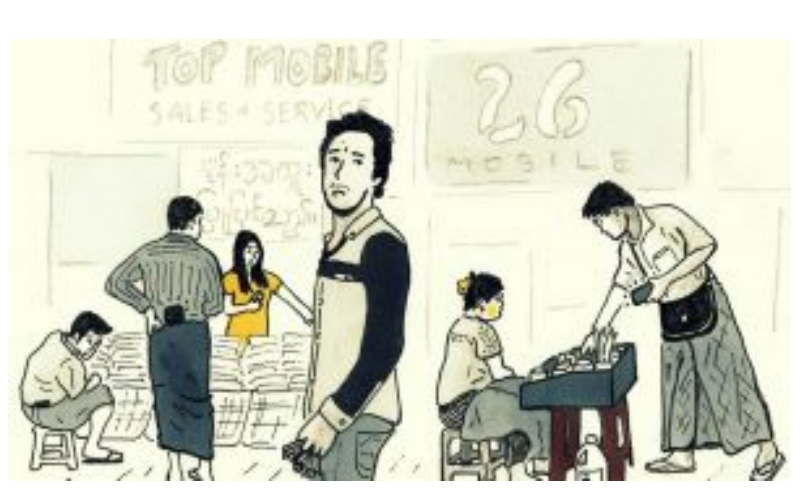

Chinese Digital Ecosystems Go Abroad: Myanmar and the Diffusion of Chinese Smartphones

Read more 


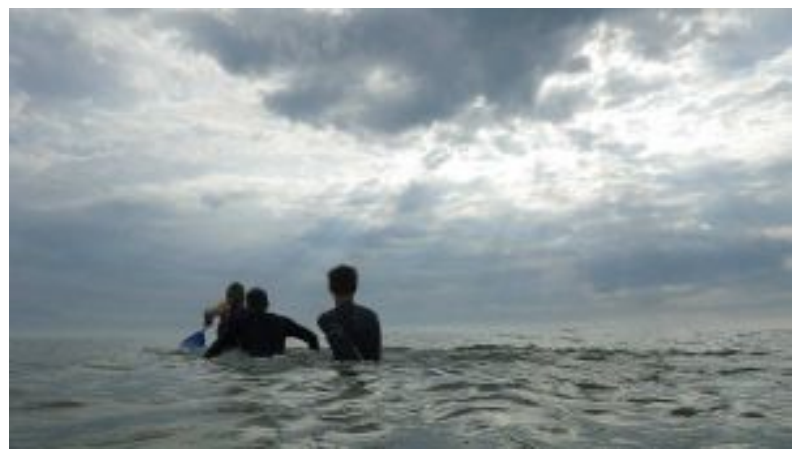

Rethinking the Cultural Politics of Globalisation: Where Do We Go from Here?

\section{Read more}

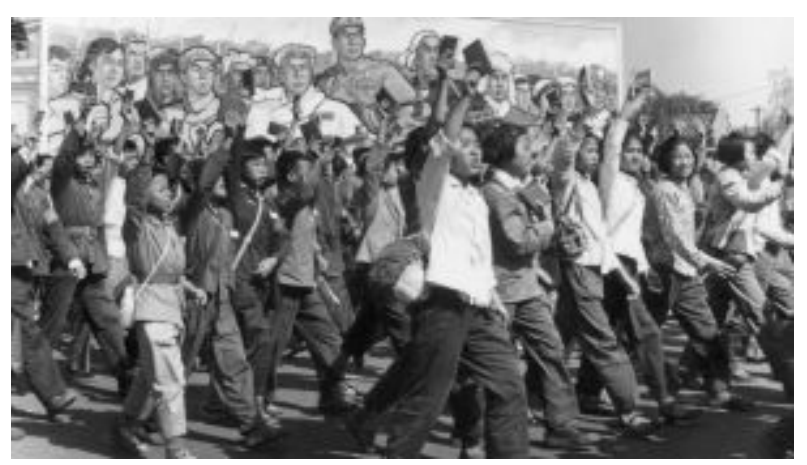

Grassroots Turmoil in China's Cultural Revolution: A Half-Century Perspective

Read more

\section{Subscribe to Made in China}

Made in China publications are open access and always available as a free download. To subscribe to email alerts for each issue of the Journal, newly published books, and information about upcoming events, please provide your contact information below. 


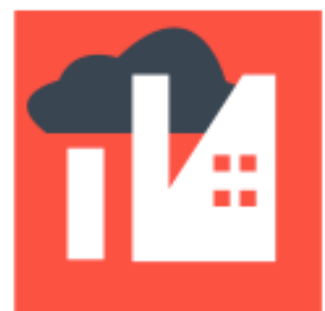

MADE IN CHINA

J $O$ O U U R N N A L

SERVICE MENU
$\oplus$ HOME
$\square$ JOURNAL
[1 ARTICLES
$R^{2}$ PRIVACY AND COOKIE POLICY SOCIAL

f FACEBOOK

TWITTER

.) RSS 